\title{
Símbolos axiales en la poesía de José Ángel Valente
}

\author{
Guillermo AGUIRRE-MARTÍNEZ \\ Docente en la Ruhr-Universität de Bochum \\ Investigador (Beca DAAD) en la Westfälische \\ Wilhelms-Universität Münster \\ guillermo.aguirre@hotmail.com
}

\section{RESUMEN}

La poesía de José Ángel Valente posee una inusual densidad simbólica favorecida por la doble aspiración de abarcar tanto el extremo más grávido y material de la creación del autor, como aquel otro más etéreo y espiritual.

Como componentes esenciales de esta búsqueda, podemos observar diversas imágenes (árbol, mandorla, hombre, cruz, etc.) que actuarán a modo de ejes simbólicos de su obra, ejes en torno a los cuales gira su universo poético.

El estudio de los diferentes símbolos axiales, así como de otra serie de imágenes entendidas como proyecciones de aquéllos (laberinto, sierpe o nube), constituye el propósito del presente trabajo, tarea en la que relacionaremos cuanto vayamos descifrando con el sentido último de la poesía de José Ángel Valente.

Palabras clave: Poesía, José Ángel Valente, Símbolo, metamorfosis, imagen, creación.

\section{ABSTRACT}

José Ángel Valente's poetry has a tremendous and unusual symbolic density. This density is favored by the author's dual aspiration to reach the spiritual limit of his creation, and the material one at the same time.

As an essential components of Valente's aesthetic search, we can observe several symbols that work like axis of his poetry. Same of they are the tree, the cross or the mandorla, whose meaning and role will be observed by us.

In this paper we will study these different symbols, as well as another images born to those axial symbols like the labyrinth, the snake, the bird or the cloud. Of course, we will link all these symbols and their role in José Ángel Valente's poetry with the ultimate meaning of his creation.

Key words: Poetry, José Ángel Valente, Symbol, Metamorphosis, Imagery, Creation.

SUMARIO: 1. El universo poético de José Ángel Valente; 2. Elementos simbólicos de transición; 3. Simbología del vuelo; 4. Imposibilidad de superación del orden natural; 5. Convergencia simbólica; 6 . Poderío del eje axial; 7. Imágenes de transformación y reunión; 
8. El reclamo de lo grávido; 9. Elementos vivificantes del universo en creación; 10. Enigmas; 11. La ruina, sombra de un orden elevado.

\section{El universo poético de José Ángel Valente}

El universo poético, en tanto que exponente de un mundo vasto y saturado de formas y significados no siempre observables en el texto, participa de un sentido simbólico encaminado precisamente a abarcar el inagotable orden de estratos oculto en las imágenes. Como proyecciones de fuerzas elementales, los símbolos, manifestados por medio de imágenes líricas, se presentarán como formas vivas iluminando una infinita serie de metamorfosis que en nada comprometen su esencia pero, a cambio, dotan de variedad y belleza a la totalidad de la creación. "La métamorphose tend peu à peu à signifier l'essence de la poésie et la faculté de transmutation des choses et des êtres qui lui appartient spécifiquement" ${ }^{1}$ permitiendo así la posibilidad de unir aquello que se nos presenta de modo desmembrado en un plano superficial pero poseedor de una fuerte cohesión en su interior. Por ello, imágenes aparentemente lejanas, opuestas en significado incluso, podrán quedar reunidas gracias a su identidad de esencia. Esta identidad, en su conjunto, se extenderá a través de una larga cadena de relaciones que aunarán unas primeras formas iniciales con aquellas otras desarrolladas por medio de una rica y constante metamorfosis.

El símbolo, qué duda cabe, será de orden anterior a la abstracción que realice la razón. De acuerdo con Jung, "no podemos inventar símbolos; cada vez que se presentan, no han sido producidos por la intención consciente y por la selección voluntaria; con ese procedimiento solo se obtienen signos y abreviaturas de pensamientos conscientes. Los símbolos nos ocurren espontáneamente [...] nos suceden" ${ }^{2}$. En consecuencia, convendrá buscar identidades internas, de esencia, atendiendo más a cuanto permanece en movimiento, a una tendencia u orientación, que a los sedimentos que podamos hallar; estos últimos tan sólo podrán proporcionarnos ciertas pautas de análisis.

Lo interesante en este aspecto será resaltar no tanto los cambios en sí como los motivos o incluso los momentos en que se producen las sucesivas transformaciones de las imágenes poéticas. Según advierte Ernst Cassirer en su Filosofía de las formas simbólicas, "el proceso simbólico es como una corriente unitaria de vida y pensamiento que surca la conciencia produciendo en ese móvil flujo la multiplicidad y cohesión, riqueza, continuidad y constancia de la conciencia"3. Frente a esta continuidad conviene mostrarse cauto, una vez que las imágenes

\footnotetext{
${ }^{1}$ M. Eigeldinger (1973), p. 7.

${ }^{2}$ C.G. Jung (2009), p. 182.

${ }^{3}$ E. Cassirer (2003b), p. 239.
} 
simbólicas tienden a envolver su cuerpo mediante diferentes disfraces. Las imágenes simbólicas quedarán hundidas en una larga cadena de transformaciones potencialmente infinita, por lo que, dada su condición pasajera, no necesariamente destacarán de modo cualitativo entre sí en la medida en que se muestran tan cercanas al reino de la cantidad como al de la cualidad, unitaria por esencia. Cabe indicar al respecto, continuando con Cassirer, que "«la preñez» simbólica que [la palabra] adquiere no le resta nada de su riqueza concreta sino que constituye la garantía de que esa riqueza no se disperse e integre una forma estable cerrada sobre sí misma" ", pues resulta evidente que ya el solo hecho de permanecer en el orden de las manifestaciones permite tomar por fiables relaciones en otro caso esquivas a ser capturadas por nuestro entendimiento. Es decir, su visibilidad, su materialidad, logra que estas imágenes resulten aprehensibles no sólo poéticamente, sino también racionalmente, permitiendo así el tan deseado encuentro entre lo sensible y lo abstracto.

En lo referente a esta posibilidad de aprehender racionalmente la imagen, creeremos que, a diferencia de Hegel, no todo lo real resulta racional ni, desde luego, representable. El símbolo, como tal, es una potencia mediadora, eco o vibración de un hecho real; en este sentido posee relación con el Ursatz que origina la creación. De acuerdo con Juan Eduardo Cirlot, pese a que "un solo fenómeno tiene lugar $[\ldots]$ sus apariciones son resonancias del mismo en diversos planos de la realidad (sonidos, colores, letras, planetas del sistema solar, dioses de la mitología, metales principales, etc.)" ${ }^{\prime 5}$. Todas esas apariciones obedecen a una serie de correspondencias comprensibles en función de un sentido interno que las unifica además de mostrarlas como potencialmente inagotables una vez que el centro y el fin convergen como esencias pero someten a las traslaciones intermedias al mundo de la cantidad, de la variación: "The religious symbols change incessantly, but the

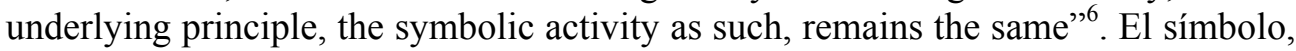
por lo tanto, presentará una doble naturaleza determinada por su doble apego tanto a lo permanente y estático, como a lo ilimitado, reverberante y potencialmente infinito.

\section{Elementos simbólicos de transición}

El ángel, uno de los elementos puente por excelencia en la poesía de Valente, se nos ofrece como primer peldaño desde donde encaramarnos en esta búsqueda de equivalencias. María Payeras Grau define a esta figura como "oponente y guardián de las regiones transparentes"7. Por su parte, Gilbert Durand considerará que el ángel es imagen "de la función simbólica misma que es -icomo ellos!- mediadora

\footnotetext{
${ }^{4}$ E. Cassirer (2003b), p. 240.

${ }^{5}$ J.E. Cirlot (2011), p. 415.

${ }^{6}$ E. Cassirer (1972), p. 78.

${ }^{7}$ M. Payeras Grau (1991), p. 7.
} 
entre la trascendencia del significado y el mundo manifiesto de los signos concretos, encarnados, que por medio de ella se transforman en símbolos"8. El mismo Durand asimismo recuerda la concepción que sobre este aspecto mantiene Henry Corbin, quien considera que el ángel nos pone en contacto con las diferentes gradaciones simbólicas del ser. En él está contenido tanto lo particular como lo general, poniendo ambos términos precisamente en relación. A este respecto, menciona el propio Corbin que "La idea de «Ángel» es la de una individualidad que es en sí misma su especie"". El ángel se desvela como elemento potencialmente destructor o, por el contrario, como eminentemente constructor. De este mismo modo lo expondrá Valente en los siguientes versos tomados de su primer libro, A modo de esperanza: "Todo empezaba así./ Todo menos la muerte,/ menos la vida,/ el amor o el/ odio./ Todo empezaba así,/ la pasión de morir,/ de vivir,/ de amar, de odiar./ Oscuro jugador,/ frente a mí el ángel/ con su terrible luz,/ su espada,/ su abrasadora verdad" 10 .

La lucha contra el ángel encarna, desde luego, la lucha por el conocimiento, por el acceso al interior del ser; el acceso, en una relación ascendente, al trono divino, solar, "hembra solar" 11 generadora de vida y, en consecuencia, fuente de la creación. El ángel se desvela como espíritu que engarza una inacabable cadena de formas, como sustancia viva que ilumina, uno a uno, los diferentes estadios que habrá de atravesar el poeta en su camino hacia "lo menos visible" 12 . Cada uno de estos estadios encarnará una forma simbólica y, desde luego, una expresión concreta menos profana, más sagrada, a medida que se asciende desde los círculos cerrados a la amplitud y apertura total de la palabra poética.

"Símbolo de lo invisible, de las fuerzas que ascienden y descienden entre el origen y la manifestación" 13 , el ángel se corresponde con una larga serie de elementos evocadores de la idea de vuelo, incorporando a su vez el concepto de límite en tanto que su aparición acontece como bisagra entre dos mundos diferenciados. La aparición del ángel iluminará un ámbito cerrado al desarrollo lineal. Su revelación enfrentará y aunará dos realidades disímiles o, en no pocas ocasiones, contrarias: luz y oscuridad, vida y muerte, tal y como apreciamos en los siguientes versos del poema "El ángel”, de Material memoria: "al amanecer,/ cuando la dureza del día es aún extraña,/ vuelvo a encontrarte en la precisa línea/ desde la que la noche retrocede./ Reconozco tu oscura transparencia,/ tu rostro no visible,/ el ala o filo con el que he luchado./ Estás o vuelves o reapareces/ en el extremo límite, señor/ de lo indistinto./ No separes/ la sombra de la luz que ella ha

\footnotetext{
${ }^{8}$ G. Durand (2007), p. 32.

${ }^{9}$ H. Corbin (2000), p. 111.

${ }^{10}$ J.A. Valente (2006), p. 72.

11 J.A. Valente (2006), p. 557.

12 J.A. Valente (2006), p. 368.

${ }^{13}$ J.E. Cirlot (2011), p. 82.
} 
engendrado" ${ }^{14}$. Al componente ya aludido de vuelo, se habrá de añadir el de sesgo, el de separación radical y, por oposición, el de reunión absoluta, que posibilitará la pretendida epifanía ansiada por el creador. Entre lo visible y lo invisible la figura angélica permite la unidad y, con ello, la continuación de la aventura poética.

El elemento de gravidez, de preñez de la materia simbólica, quedará relacionado con todo lo que permanece entregado a la generación. De momento, cuanto nos interesa nos lleva a fijarnos en aquello que permite elevar el vuelo desde un estado larvario a aquel otro estado capaz de posibilitar la concreción de la expresión. Así, en el poema "Rotación de la criatura" leemos que "La semilla contiene todo el aire; el grano es sólo un pájaro enterrado; la nube y la raíz sueñan lo mismo"15. La convergencia entre raíz o semilla y nube o fruto, entre origen y llegada, permite presenciar algo que estudiaremos más adelante y que concierne a una idéntica búsqueda realizada por medio de dos caminos diferentes, el primero de ellos recorrido a través de elementos pasivos, y el segundo a través de elementos activos.

\section{Simbología del vuelo}

Como bien señala Juan Manuel del Río Surribas, "el vuelo es un perpetuo estado de negación de la cristalización de la forma"16. A falta de atender a una total suspensión del vuelo, tal y como podremos observar en la última poesía de Valente, el pájaro participa por lo general de una constante necesidad de transformación, emergiendo como símbolo hacia un cielo más grisáceo y oclusivo que azul y abierto dado lo complicado que resultará el acceso hacia una dimensión entregada a lo eterno. El pájaro se elevará sobre toda materia solidificada, sobre los terrenos pantanosos que el hombre, el poeta, atraviesa en aquellos momentos en que se nos muestra separado de su dinamismo espiritual. Será en estos parajes elevados donde la carga simbólica del ángel resulte más densa una vez que habrá ido acumulando todas aquellas cualidades recogidas a lo largo de su trayecto poético. En paralelo, la creación, dada su doble naturaleza, tardará en alcanzar el desarrollo completo de su forma unitaria, definida por la relación ascendente y entrelazada que avanza desde el pez a la sierpe y, por último, a un ave que remonta unos estadios puramente materiales para adentrarse en las alturas atraída por una nada intangible, inefable, comprendida como punto de llegada.

Esta búsqueda realizada en dos horizontes opuestos que acabarán por converger, sustituirá a aquella otra desarrollada en un plano horizontal aún perfectamente visible en la primera poesía del autor. La dualidad manifiesta entre horizontalidad y verticalidad quedará superada por el poeta, suponiendo esta superación a su vez el

\footnotetext{
14 J.A. Valente (2011), p. 379.

15 J.A. Valente (2006), p. 134.

${ }^{16}$ J.M. Ríos Surribas (2009), p. 213.
} 
paso de una conciencia histórica a otra ahistórica y atemporal. Se trata, en definitiva, del hegeliano salto de la cantidad a la cualidad. Este mismo proceso lo explica detalladamente Paul de Man en las páginas de Visión y ceguera cuando señala que

la transformación que le permite al artista pasar de la autoexpansión y el autodesarrollo a la conquista de un tipo de yo completamente distinto, la describe Binswanger en la metafórica vertical del ascenso y el descenso. La fenomenología de las lejanías, dominio del hombre de acción, queda reemplazada por una fenomenología de las alturas y las profundidades: el paisaje horizontal de la llanura y el mar se convierte en el paisaje vertical de la montaña. La fragilidad de esta trascendencia poética, a diferencia de la relativa seguridad de la acción directa, aparece representada por la angustia de las alturas. Las idas y venidas del trotamundo o del navegante son acciones voluntarias y controladas, pero la posibilidad de la caída, que imponen al alpinista fuerzas externas, sólo existe en el espacio vertical. Lo mismo sucede con las experiencias que están estrechamente vinculadas a la caída, como el vértigo o la recaída. Es decir, que la muerte está presente de manera más radical en la experiencia de lo vertical, que en la experiencia de la vida horizontalmente activa. A la posibilidad de la caída corresponde la de un ascenso igualmente involuntario ${ }^{17}$.

De modo similar se representará esta experiencia en el poema en la medida en que no siempre el pájaro podrá mantener el vuelo: en estas ocasiones el ángel callará. El abismo entre el poeta y el objeto poético se abrirá brusco, propiciando la caída del yo. Se trata, en fin, de la imposibilidad de unir visión fenoménica con visión absoluta: "entre el ojo y la forma / hay un abismo", mediante la abolición completa del sujeto creador:

Llega un momento en que Valente, en busca de nuevos horizontes poéticos, inicia una premeditada desposesión de su memoria personal. [...] Se busca simbólicamente «la propia muerte» en busca de una nueva e inocente identidad; el yo poético estrangula «con suavidad premeditada» a su enemigo que no es más que su propio yo pasado ${ }^{19}$.

permitiendo un conocimiento profundo de lo real, no mediante la posesión, sino gracias a la confluencia entre sujeto y objeto, entrega mutua de la creación en un común espacio de deseo.

La intención de mantenerse firme en estas alturas, de consolidar el vuelo, fructificará por sólo unos instantes, resultando al momento fallida una vez que el espesor del cielo gris no parecerá franqueable por la voz del poeta, exhausta y

\footnotetext{
${ }^{17}$ P. de Man (1991), pp. 55-56.

18 J.A. Valente (2006), p. 113.

${ }^{19}$ A. Romarís Pais (2000), p. 162.
} 
desgarrada ante la imposibilidad de aprehender lo indecible: "Quién pudiera andar/ sobre las aguas verdes/ de este mar/ Y por el aire gris/ quién pudiera, mar grande, dejarse ir" ${ }^{20}$. Al deseo de trascendencia le sobrevendrá, sin salir de Breve son, la contemplación de su caída: "Duro cielo de piedra/ despeñado en lo hondo./ Barranco grande./ Camino roto".

Prosiguiendo con Paul de Man, encontraremos un comentario alusivo a esta doble orientación:

Bachelard y Binswanger discuten cómo en el acto de la imaginación pura, el yo «se siente llevar», con la sensación de un levitar. [...] La transcendencia poética está íntimamente relacionada con este ascenso espontáneo, que asemeja un acto de gracia, aunque no es más que la manifestación del deseo. Como resultado el «bajón» subsiguiente, la posibilidad de la recaída y abatimiento que sigue a los vuelos momentáneos, es mucho más trágica y definitiva que la simple fatiga de quien desciende, por sus propios medios, al mundo inferior del quehacer cotidiano ${ }^{21}$.

Así, en este orden poético que venimos estudiando, por muy patente que resulte el componente místico, al deseo de trascender lo puramente material le sobrevendrá una caída espiritual, pues la acción no deja de desarrollarse dentro de un plano estético, es decir, sin que se haya producido en momento alguno el salto hacia lo religioso.

\section{Imposibilidad de superación del orden natural}

La estancia en las alturas, como indicamos, no se afianzará. El cielo gris se mostrará a modo de muro, de sólido techo imposible de rebasar. El ángel, el pájaro, el ala, todos ellos simbólicamente entrelazados, se mostrarán entonces como imágenes de vuelo pero también de inminente caída. No hará falta indicar que detrás de este deseo de ascensión se esconderá una fuerte tendencia mística despertada ante la imposibilidad de observar al dios en la materia, en los estratos inmanentes de su poesía. La imagen, asimilada con el fetiche, con el símbolo de poder, no será tolerada al presentarse como intermediaria y obstructora de aquello que Valente desea alcanzar de modo directo y sin velo alguno. Todo aparato intermedio, incluida la palabra, impedirá, consecuentemente, la unión inmediata del sujeto con la divinidad.

Por su parte, únicamente en los momentos en que símbolos de búsqueda y símbolos de acogida convergen, resultará posible una fugaz epifanía de la divinidad dentro de una dimensión poética. Entretanto, se irá produciendo la caída, el desgarro, el lamento: "Línea o modulación, apenas/ trazo, tentativa del cuerpo, envite/ oscuro/ del ángel que aún no puede/ afirmarse en el borde/ sumido de la

\footnotetext{
${ }^{20}$ J.A. Valente (2006), p. 244.

${ }^{21}$ P. de Man (1991), p. 56.
} 
luz" ${ }^{22}$. La caída se consuma, la palabra arde tras este momento de confrontación, quedando el poema como reflejo de aquello que no ha podido elevarse con éxito hacia el absoluto. El verbo, ave fénix de la creación, quedará sobre tierra en forma de ceniza, de residuo, despojo de cuanto en su momento fue furioso deseo: "Cielo rasante/ Pájaros./ Ceniza./ Ciega,/ rota imagen borrada, indescifrable,/ extinta"23. Símbolos de ascensión trazarán en estos momentos una vertiginosa caída, quedando consolidada -aun en sentido inverso al anterior- la cadena que aúna la forma con la sustancia.

Cielo, nubes, sol, por citar unos pocos motivos, se manifestarán por lo común como objetos reacios a la transparencia, fuentes de incertidumbre y de temor, estáticos en unas ocasiones, sombríos por lo general; imágenes, en fin, fácilmente dadas a establecer una separación radical entre espacio real y espacio trascendental. "Izose un cielo gris sobre las rotas alas" ${ }^{24}$, leemos en el poema "Elegía", de Material memoria. Va a ser en aquel espacio situado más allá del curso natural de la historia donde el poeta espere encontrar un lugar de comunión con la divinidad, una divinidad ajena al orden que se ha consolidado en el marco de lo real. La salida hacia lo no manifestado, hacia lo no condecorado con un sentido definido, es salida, a su vez, hacia la libertad; experiencia, en cualquier caso, fracasada dado que al poeta no le resultará posible despojarse de su naturaleza material, hasta el punto de hablarse, si se quiere hablar de mística, precisamente de una mística material ${ }^{25}$.

La inmersión consciente en la materia devendrá de un deseo connatural al poeta originado por su deseo de proveerse de formas y elementos tangibles, carnales, requeridos de cara al natural desarrollo de su creación. En "El descenso del crepúsculo esta tarde" podemos leer, sintomáticamente:

Esta luz gris de las nubes que es como una madre, gris, gris, gris, gris, a su seno me atiene. Y yo, quién, se duerme hacia lo hondo, como bajando escalas por lo gris del aire, que las nubes maternas cobijan. Yo, quién, se duerme como quien dormido desde su propio sueño se velara. Ando, me digo, a quién, sobre las aguas. No me despiertes más que a ti, en el fondo, oscuro el fondo, en ti, oscura madre ${ }^{26}$.

${ }^{22}$ J.A. Valente (2006), p. 465.

${ }^{23}$ J.A. Valente (2006), p. 468.

${ }^{24}$ J.A. Valente (2006), p. 380.

${ }^{25}$ Indica Bernard Noël al respecto que,

en cuanto a la mística, me parece que siempre tendemos a olvidar que no hay mística sin técnica corporal, y que la mística es una manera de unir el cuerpo al pensamiento y a la meditación. Y me parece muy importante en el caso de Valente, porque la irrupción de la mística en su obra supone también la irrupción del cuerpo, la presencia de la mística en su obra supone también la irrupción del cuerpo, la presencia del cuerpo en su pensamiento y en su vida. B. Noël (2008), p. 35.

${ }^{26}$ J.A. Valente (2006), p. 383. 
Palabras cálidas y tiernas en cuanto indicativas de la cercanía del creador con la materia fecundante.

Desde luego, mucho más propicios resultarán para José Ángel Valente aquellos elementos que considerará como maternos, tierra y agua, de función acogedora y continente, que aquellos de orden propiamente paternal, aire y fuego, enemigos de lo sensual, de la permanencia en un plano real y aprehensible. Qué duda cabe que la búsqueda provechosa y menos desoladora de nuestro poeta se realizará en las honduras del espacio poético, al calor de una inmanencia donde se asentará un dios de origen dionisiaco; aspecto, pese a todo, rechazado por el poeta en la medida en que aspira a la contemplación de aquella deidad que se encargue no ya de su cuerpo sino de su espíritu. Este último deseo, sin embargo, como ya vimos, chocará al contacto con un cielo manifestado a modo de velo, infranqueable distancia entre lo real y lo infinito. Por todo ello, podemos observar cómo la propuesta de Valente por alcanzar la totalidad se realiza preferentemente en un orden órfico. En cualquier caso, si bien es cierto el gusto por lo material manifestado por el poeta, su ansia de trascendencia concluirá, aun frustradamente, con una búsqueda fatigosa tendente a rebasar el mundo de lo fenoménico. Podemos concluir esta cuestión indicando la existencia en Valente de una poesía material, pagana y rica en imágenes, que será abandonada en pos de una búsqueda de lo trascendental remitente a una espiritualidad monoteísta, búsqueda fracasada en tanto que el poeta no logra caminar a oscuras precisamente donde resulta necesaria una completa oscuridad.

\section{Convergencia simbólica}

A continuación observaremos el modo en que los diferentes símbolos alcanzan una comunidad de sentido intercambiable mutuamente, de modo que la imagen gana en riqueza como resultado de la plurivalencia posibilitada por la densidad poética. En los siguientes versos de Material memoria presenciamos cómo las nubes terminan por tornarse alas y aves derribadas una vez que su cuerpo se detiene ante la incapacidad de avanzar hacia un ámbito intangible, abstracto:

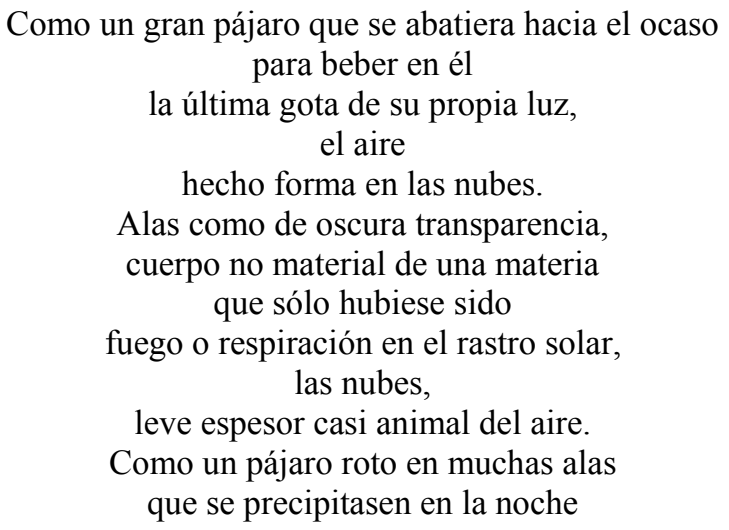


ebrias de luz,

las nubes ${ }^{27}$.

Detrás de esta asimilación se encierra, obviamente, una identificación entre el objeto y el sujeto poético. Así, este último, una vez realizada dicha transferencia, pasará a devenir en ala, en palabra, o en cualquier otro símbolo finalmente derrotado en la lucha contra el objeto. Sujeto lírico y objeto ya no colisionarán, rompiéndose la barrera entre mundo interior y mundo exterior una vez que queda sin valor la anterior perspectiva narcisista. Sylvia R. Sherno realizará alusión a "an exact equivalent between those components which the punctuation is designed to separate. The crossing of matter and spirit [...] has constituted one of the constants of Valente's work since early in his career. Indeed, the desire to annul disparities underlies his vision of poetry" ${ }^{28}$. La superposición simbólica procederá, consecuentemente, de una transparencia de visión, de un erosionar los límites que impiden la convergencia $\mathrm{y}$, con ello, la capacidad de irradiación de los símbolos poéticos. Esta anulación de la individualidad, del yo, habrá posibilitado la ampliación de nuestro universo simbólico; alcanzándose así una correspondencia cósmica dado que la voluntad creadora se va a manifestar a través de cada una de las sustancias que en la poesía actúan como fuerzas vivas, siendo ella misma el lazo que une a cada una de esas formas y las subsume en una unidad presentida. En consecuencia, la nube gris resulta una identificación, en último término, con un absoluto al que no puede accederse, sin que ello la excluya, una vez mutada su forma en ala, de devenir ahora en espíritu errante y desesperanzado tras no haber alcanzado el estadio superior denodadamente perseguido. La voluntad creadora presentará así una naturaleza divina pese a que habrá de caminar por el farragoso barro de la mano de la historia. Se da, por lo tanto, una correspondencia microcosmos-macrocosmos entre el creador y el universo del poema, pues la representación no será sino la proyección de una vivencia espiritual acontecida en el interior del poeta. Ilustrativo resulta en este aspecto el comentario de Henry Corbin al mencionar que

el Adorado se hace en él mismo el Adorador, y este acto no ha comenzado con la existencia del fiel en el tiempo, sino que se realiza desde la preeternidad en las esencias virtuales de los seres. La pregunta formulada por el Ser divino a la masa primordial de las existencias arquetípicas, “¿No soy yo vuestro Señor?” [...] es, en este sentido un diálogo del Ser divino con su "Sí", una pregunta que se dirige a sí mismo en ellos y a la que responde a través de ellos. Pacto de una "sympathesis" preeterna. Por eso es imposible que el Ser divino se separe (y absurdo

${ }^{27}$ J.A. Valente (2006), pp. 382-383

${ }^{28}$ S. Sherno (1989), p. 170. 
que nosotros lo separemos) de las formas del universo, es decir, de los seres que adorándole le hacen Dios, porque su adoración, es decir, su teopatía, es la forma de la Compasión (sym-pathesis) divina com-padeciendo con ellos: él mismo se adora en todos sus seres que son sus teofanías, aunque no todos las perciben, pues son muchos los seres que no perciben la oración del Silencioso (al-Sâmit), la oración del heliotropo, por ejemplo, que tan justamente percibiera Proclo ${ }^{29}$.

La aclaración, un tanto correosa, apuesta por una divinidad manifestada como forma viva en cuerpo y esencia a través de su creación, aspecto que de nuevo nos guía hacia un cosmos donde el interior de cada ser resulta identificable con la esencia divina, asimilada por lo general con una oscura nada, resultando esta misma nada -absolutamente necesaria para dar el salto hacia lo absoluto-, la dura piedra con la que tropiece y caiga Valente de modo reiterado en su deseo de abrazar lo trascendental:

El poeta, ante la imposibilidad de acceder a lo divino, tratará de encontrar a la divinidad en su interior, resultándole, sin embargo, imposible hallar más que tinieblas, no pudiendo salir del limitado espejo de la inmanencia. El creador rastrea de este modo cada uno de los vértices de una creación -presentada como proyección natural de su yo- con el propósito de dotar de sentido trascendente a la existencia una vez que quede al descubierto la divinidad que acaso habita el interior. Sin embargo, en este cerco definido por el yo, no hará aparición sino un dios material vivificador pero, a un mismo tiempo, devorador. Por este motivo, tras realizar su incursión en la materia, ante el escaso éxito de su aventura, el poeta tratará de aproximarse, tal y como hemos ido observando, a un Dios situado en un orden externo a la creación.

Se trata pues, -dirá Dionisio Cañas-, de escribir desde la noche y para la noche, porque en verdad el viaje iniciado por Valente es similar al del místico, y su aspiración última es la búsqueda de esa noche oscura a través de la cual, vaciada incluso la escritura de su contenido, una oquedad, una nada, un vacío, permitirían el verdadero nacimiento de algo más trascendental ${ }^{30}$.

\section{Poderío del eje axial}

Dentro de esta indagación inclinada a unir el yo con la divinidad, el árbol -ya en unos dominios menos errantes, más cohesionados- se va a manifestar como imagen lograda de la totalidad. Como símbolo axial, el árbol pondrá en relación los diferentes órdenes del poema, resultando especialmente patente aquel que aúna el agua y la tierra con un orden superior aéreo. Afirma al respecto Cirlot que

\footnotetext{
${ }^{29}$ H. Corbin (1993), p. 151.

${ }^{30}$ D. Cañas (1984), p. 187.
} 
tratándose de una imagen verticalizante, pues el árbol recto conduce una vida subterránea hasta el cielo, se comprende su asimilación a la escalera o montaña, como símbolos de la relación más generalizada entre los «tres mundos» (inferior, ctónico o infernal; central, terrestre o de la manifestación; superior, celeste) ${ }^{31}$.

El árbol recrea un cosmos completo, siendo, por ello mismo, representación del ser humano. Ambos se erigen como eje axial, como centro de la creación y símbolo de unión de cuanto conforma el espacio del poema. Precisamente, su ubicación a modo de ombligo del universo le confiere la capacidad de poder consagrarse como lugar de epifanía, de convergencia entre naturaleza terrena y naturaleza divina. El árbol, en su realización completa, albergará los distintos elementos cósmicos pertenecientes tanto a los márgenes superiores como a aquellos otros inferiores: en la copa posará el ave, así como el rayo de la luz procedente del sol que atraviesa el aire; a sus pies se enroscará la serpiente, encarnación de la tierra; bajo el árbol, alimentándole en silencio, las aguas que han de ser bebidas por las raíces, aguas generadoras de vida que treparán por el tronco abriéndose camino hacia la luz. Al tratarse, como sabemos, de un árbol cósmico, de un árbol de la vida y de la muerte, se entra en relación con el universo plurivalente propio del gran símbolo. El árbol no encarnará así, en su versión plenamente realizada, una imagen parcial sino una fuerza unitiva, un universo completo observable a modo de imagen poética consolidada y sin desarrollo al margen de él, pues todo el orden de lo creado quedará representado en su interior.

Los diferentes estratos simbólicos recién comentados resultan especialmente observables en el poema "Elegía, el árbol", de Interior con figuras, donde el autor se detiene pausadamente en las cualidades simbólicas que venimos comentando: "El árbol pertenecía por la copa a lo sutil, al aire y a los pájaros. Por el tronco, a la germinación y a todo lo que une lo celeste con los dioses del fondo. Por la raíz oscura, a las secretas aguas. La copa dibujaba un amplio semicírculo partido. Porque también el árbol era portador del fuego, herido por el rayo, el árbol"32. El recorrido, como vemos, es completo: desde las honduras hasta la cima, con el fuego como elemento mediador entre ambos extremos. A continuación, tomándose su forma total y realizada, se alude al árbol como centro, como "forma que en la cercanía del dios reviste lo viviente", para finalmente mencionarse que el árbol es talado y sustituido por el hombre, tratándose ambos de símbolos hermanos, participantes no de una dimensión existencial sino esencial, no destacando tanto por su verticalidad como por el círculo que simbólicamente queda trazado de la copa a las raíces, de la cabeza a los pies y, en su dimensión horizontal, por la extensión de los brazos.

\footnotetext{
${ }^{31}$ J.E. Cirlot (2011), p. 89.

${ }^{32}$ J.A. Valente (2006), p. 359.
} 
El hecho de que el árbol quede talado nos da pie a tratar la separación del plano onírico respecto del espiritual, separación resultante, como podemos suponer, del predominio de las fuerzas racionales sobre las simbólicas. Será necesario un esfuerzo anímico consistente en la búsqueda voluntaria de una unión no permitida para que se supere el sesgo que conlleva toda naturaleza parcialmente desarrollada. El espectáculo del árbol derribado, en cualquier caso, mostrará lo infructuoso de la ligazón mantenida con la naturaleza, una vez que los elementos tierra y agua pierden toda su potencialidad al quedar al margen de un orden ontológico superior. Las potencias ctónicas, separadas del plano superior, se impondrán sobre la fuerza espiritual; el poder de engendrar residirá intacto pero impedido de dotar de forma a la materia. La raíz, aunada simbólicamente con el ave, con el cielo, queda despojada de sentido y, en cierto modo, de ser. El poeta advertirá, "No separes/ la sombra de la luz que ella ha engendrado",33.

\section{Imágenes de transformación y reunión}

La serpiente, al igual que el pez, se va a manifestar como símbolo asociable a la raíz. Cada uno de estos símbolos buscará a su modo la elevación, la forma, el crecimiento, tras presentarse en un primer momento en estado larvario. La luna, asociada al pez, manifestará, como la sierpe, un poder transformativo llamado a la ascensión y, por lo tanto, a la resurrección. De acuerdo con Bachelard, "la raíz es el árbol misterioso, es el árbol subterráneo, el árbol invertido"34, y por ello mismo prefiguración del árbol cósmico. El árbol, reunidos todos sus órdenes en el templo que él mismo constituye, acabará finalmente por brotar. Ya en el siguiente poema asistimos, una vez más, a la unión del espacio maternal donde se genera la creación, el agua, con el componente aéreo a través de la sierpe, lograda representación del dinamismo poseído por todo elemento entregado a la metamorfosis. Así ocurre con la recién mencionada sierpe o con el fuego: "engéndrame de nuevo: hazme morir de un nuevo nacimiento: respírame y expúlsame: animal de tus aguas: pez y paloma y sierpe" ${ }^{35}$. Estas diferentes imágenes, en tanto que pertenecientes a un orden mítico, ponen al poeta en contacto con los ciclos de reencarnación de la materia, es decir, tienden por inclinación natural hacia su polo opuesto, mostrándose potencialmente aunadas al símbolo de vuelo: "en el descenso oscuro/ del paladar a la materia húmeda/ lo amargo llen / de pájaros raíces el deseo"36.

La figura del pájaro-raíz será la concreción de esta unión entre opuestos, denotando una feliz realización espiritual dado que los estadios primarios del ser proveen de riqueza a aquellos otros elevados, espirituales. La representación detallada la encontramos en el poema "Palabra", de Material memoria:

${ }^{33}$ J.A. Valente (2006), p. 379.

${ }^{34}$ G. Bachelard (2006), p. 326

35 J.A. Valente (2006), p. 401.

${ }^{36}$ J.A. Valente (2006), p. 385. 


\author{
Palabra \\ hecha de nada. \\ Rama \\ en el aire vacío. \\ Ala \\ sin pájaro. \\ Vuelo \\ sin ala. \\ Órbita \\ de qué centro desnudo de toda imagen. \\ Luz, \\ donde aún no forma \\ su innumerable rostro lo visible ${ }^{37}$.
}

En este caso, la proyección ascendente del poema queda compensada y orientada mediante un eje, centro cósmico en torno al cual el imaginario gravita. El centro es piedra, polo, ombligo del universo, imagen de completitud y permanencia, totalidad integrada. Jung relacionará este centro con la idea del sí-mismo, y éste a su vez con la figura del lapis $^{38}$. De acuerdo con René Guénon, "para realizarse totalmente, es necesario que el ser escape de este encadenamiento cíclico y pase de la circunferencia al centro, es decir, al punto en que el eje se encuentra con el plano que representa el estado en el que este ser se encuentra actualmente" ${ }^{39}$. El presente hecho permite adivinar un estadio de reunión total de contrarios sobre un plano concreto. No obstante, esta concreción material aparecerá en la poesía de Valente dibujada en no pocas ocasiones a modo de centro inasequible, inalcanzable o, en cualquier caso, meramente atisbado: "Piedras. Norte. Estalla/ lejos la luz, muy lejos./ Andemos todavía" ${ }^{40}$; distinguiéndose la luz pero desconociéndose la puerta por donde se accede a ella.

${ }^{37}$ J.A. Valente (2006), pp. 378-379.

${ }^{38}$ Señala Jung:

El alquimista hace resaltar siempre su humilitas y comienza sus tratados con invocaciones a Dios. Ni remotamente piensa en identificarse con Cristo; por el contrario, la alquimia establece un paralelo entre la sustancia buscada, el lapis y Cristo. No se trata probablemente de una identificación, sino del sicut (como si) hermenéutico, que indica la analogía. Pero para el hombre medieval la analogía es menos una figura lógica que una identidad secreta, lo cual es un residuo aún muy vivo del pensamiento primitivo. [...] El fuego es como Cristo (imago Christi). La piedra, de la cual surge la chispa, es la "piedra angular", otra imago, y la chispa que salta de la piedra es asimismo una imago Christi. C.G.Jung (2005), p. 226.

${ }^{39}$ R. Guénon (2003), p.160.

${ }^{40}$ J.A. Valente (2006), p. 547. 
Como mencionamos, el paso de un eje horizontal a un eje vertical será de naturaleza cualitativa, del mismo modo que también lo será el del eje vertical al eje central o axial donde todo polo queda concentrado en la unidad ${ }^{41}$. Guénon añade que "mientras que hay continuidad entre todos los estados considerados en su recorrido cíclico [...], el paso al centro implica esencialmente una discontinuidad en el desarrollo del ser" ${ }^{\circ 2}$. La tensión representada por los elementos se volverá hacia el centro de modo que el poeta, el verbo, se encuentra en esos momentos fuera de toda dimensión temporal, perdiéndose cualquier posibilidad de desarrollo lineal, cronológico, una vez que hay convergencia de contrarios. Este salto, en definitiva, supone una superposición del fenómeno religioso sobre el fenómeno estético, objetivo hondamente buscado en diferentes momentos de la creación del poeta.

El elemento sagrado, nuclear por excelencia en la poesía de Valente, lo encontramos en el conocido símbolo de la mandorla, comprendida como espacio de germinación, como núcleo de su universo. Al respecto, se pregunta Heidegger:

El espacio ¿pertenece a esos fenómenos primarios que, al ser descubiertos, despiertan en el hombre, según palabras de Goethe, una suerte de espanto que llega a convertirse en angustia? Pues parece que detrás del espacio no hay nada más a lo cual éste pudiera ser reconducido. Y delante de él no hay desvío que lleva a otra cosa. Lo peculiar del espacio tiene que mostrarse a partir de él mismo. ¿Se deja decir todavía su peculiaridad? ${ }^{43}$.

Desde luego, resultará conveniente diferenciar entre un espacio abierto y un espacio habitado. La apertura es un requerimiento para la posterior habitabilidad, pero no implica su consecución, quedando en ocasiones este espacio desocupado $\mathrm{y}$, por lo tanto, llenando al poeta del terror al que alude Goethe ante la infinitud de lo contemplado. La mandorla, como espacio sagrado, resultará terreno propicio para la aparición del dios, un espacio donde la nada va a habitar, desconociéndose en cualquier caso el sentido exacto de esa vacuidad, pues la poesía de Valente

${ }^{41} \mathrm{Al}$ respecto, Guénon aclara que

La posición horizontal es la de dos términos que, situándose en un mismo grado de realidad, son simétricos, por decirlo así, desde cualquier punto de vista; la oposición vertical marca por el contrario una jerarquía entre los dos términos que, siendo simétricos en tanto que complementarios, deben ser considerados uno como superior y el otro como inferior. [...] En efecto, la esencia y la substancia universales son respectivamente el polo superior y el polo inferior de la manifestación, y se puede decir que una está propiamente por encima y la otra por debajo de toda existencia; por otra parte, cuando se las designa como Cielo y Tierra, esto se traduce también, de forma muy exacta, en las apariencias sensibles que les sirven de símbolos. R. Guénon (2004), p. 30.

${ }^{42}$ R. Guénon (2003), p. 160.

${ }^{43}$ M. Heidegger (2009), p. 19. 
desconfía y, en consecuencia, rehúye de lo exacto. Así, en el poemario que toma precisamente como título Mandorla, leemos:

AGUARDÁBAMOS la palabra. Y no llegó. No se dijo a sí misma. Estaba allí y aquí aún muda, grávida. Ahora no sabemos si la palabra es nosotros o éramos nosotros la palabra. Mas ni ella ni nosotros fuimos proferidos. Nada ni nadie en esta hora adviene, pues la soledad es la sola estancia del estar. Y nosotros aguardamos la palabra" ${ }^{44}$.

La palabra será el centro, origen -y nos remitimos a San Juan- de la creación. Este espacio nuclear no siempre será lugar de epifanía, pues, en definitiva, ésta va a escapar a la realización estética, guardándose el tesoro para el fenómeno religioso. De acuerdo con Victoria Cirlot, la naturaleza dual de la mandorla "se justifica por su participación en los dos mundos (el celestial y el terrenal), y su importancia decisiva al ser el único punto de contacto posible entre ambos, allí donde la comunicación se hace efectiva" ${ }^{\$ 5}$. La aludida comunicación es, evidentemente, la que se produce entre una palabra material, humana, y una palabra divina, de naturaleza inefable e inaprensible, que el poeta, no obstante, persiste en alcanzar. $\mathrm{La}$ mandorla vendrá a significar la unidad elemental, pero no la aparición de lo inefable, de un dios cuya contemplación, de llegar, lo hará de manera supraestética, espiritual.

En este sentido, la lucha poética contra el ángel podrá ser ganada, resultando posible alcanzarse un estadio místico, una superación de la dimensión racional siempre y cuando se dé una creencia absoluta en la identidad positiva de la divinidad. No es el caso de Valente, quien, pese a lograr erigir el templo necesario para el acontecimiento religioso, carecerá de la fe ciega que le permitirá habitar serenamente en su interior. Con relación a este aspecto, y citando a Ibn 'Arabī, Corbin indicará que

lo que un ser alcanza en la cima misma de su experiencia no es, no puede ser, el fondo de la Esencia divina en su unidad indiferenciada. Es ésta la razón por la que Ibn "Arabī rechazaba la pretensión de ciertos místicos que pretendían "llegar a ser uno con Dios". Lo que un ser humano alcanza en la experiencia mística es el "polo celeste" de su ser, es decir, su persona como entidad en la cual y por la cual el Ser divino se manifestó a sí mismo en el origen de los orígenes, en el mundo del Misterio, y a través de la cual se hizo conocido en la Forma, Forma por la que también él se conocía en esa persona. Lo que alcanza es la Idea o, más bien, el "Ángel" de su persona, de la que el yo presente no es más que el polo terrestre ${ }^{46}$.

\footnotetext{
${ }^{44}$ J.A. Valente (2006), p. 423.

${ }^{45}$ V. Cirlot (2010), p. 66.

${ }^{46}$ H. Corbin (1993), p. 316.
} 
De acuerdo con el estudioso francés, no habrá convergencia anímica entre dios y hombre, sino entre este último y el símbolo que le pone en relación con la divinidad, disociándose así un plano de conocimiento personal de aquel otro de índole divina. La epifanía continuará reservada para una religiosidad al margen de la incesante búsqueda. Ésta podrá posibilitar aquélla, pero en ningún caso la determinará; abrirá el espacio, pero por sí misma no lo llenará.

La consecución del centro será, por idéntico motivo, concreción poética, concentración máxima y ámbito de posibilidad, pero no de consecución de la epifanía. La mandorla representará la consecución de un espacio, un reino de ser, no el acercamiento divino al interior de dicho reino. Apunta Heidegger en lo referente a este asunto que "tendríamos que aprender a reconocer que las cosas mismas son los lugares y que no se limitan a pertenecer a un lugar" búsquedas de Valente en un orden trascendental, esta anterior noción le resultará válida poéticamente una vez que todo objeto podrá llegar a poseer la cualidad de centro, de lugar, sin embargo no le ayudará de cara a tratar de encontrar al dios en un eje cósmico, pues el centro, en su caso, no implicará religiosidad, siendo así la propuesta del pensador alemán válida para una feliz permanencia en un plano inmanente pero no así de cara a satisfacer el deseo de realización metafísica que con tanta urgencia demanda el poeta gallego.

La mandorla, con todo, como espacio habitable se manifestará a modo de enclave propicio para el surgimiento de la voz, "con las manos se forman las palabras,/ con las manos y en su concavidad/ se forman corporales las palabras/ que no podíamos decir" ${ }^{48}$; pese a ello, la imposibilidad de decir subsistirá puesto que no hay señal de proyección espiritual. Así, el espacio sagrado por excelencia, el hombre, el centro, el cuerpo, llegará a perecer sin que la divinidad logre manifestarse en él: "Y todo lo que existe en esta hora/ de absoluto fulgor/ se abrasa, arde/ contigo, cuerpo,/ en la incendiada boca de la noche" ${ }^{\text {49 }}$, dejando sobre el poema, visibles, las cenizas, pero no así el espíritu de las palabras con que concluye el poemario El fulgor.

\section{El reclamo de lo grávido}

En el extremo opuesto a la mandorla, como manifestación de lo no reconciliable, de lo duro, lo no tendente a la unión con otros objetos, la arena cobra un papel importante. Ya desde un primer momento, en A modo de esperanza, observamos al sujeto poético cruzando un desolado y fatigoso desierto. Según Peinado Elliot: "el desierto adquiere [...] una dimensión universal, como lugar cercano a la nada, en el que se desvanecen todas las seguridades. Asistimos en el

\footnotetext{
${ }^{47}$ M. Heidegger (2009), pp. 25-27.

${ }^{48}$ J.A. Valente (2006), p. 453.

${ }^{49}$ J.A. Valente (2006), p. 458.
} 
desierto a la descomposición de las imágenes, a la corrosión de todo lo vivo, que se muestra en su condición mortal" ${ }^{, 50}$. El desierto se mostrará, por una parte, como inmenso espacio donde no hay lugar para la aparición de elementos animados, extensión tan vasta y silenciosa como la profundidad de la pregunta alusiva al sentido último del camino. El desierto callará, dejando al poeta sumido en la soledad y con el desconocimiento de cuándo se producirá aquella salida al mundo que le permitirá marchar hacia el encuentro del objeto, del ángel ${ }^{51}$. Por otro lado, el desierto se presentará como el lugar desde donde se realizan las preguntas sin que se obtenga respuesta alguna; lugar, por tanto, de sufrimiento. Dada la carencia de agua, de fuente o de espejo donde se refleje el propio sujeto, esta tierra mostrará una opacidad, una incapacidad de presentar correspondencias en un plano simbólico y, con ello, una imposibilidad de ganar terreno a la aridez por la que camina el poeta.

El desierto es, a su vez, también el lugar de la espera, presagio primero de una posible aparición, de la revelación que, más adelante, algún día, habrá acaso de acontecer; y paralelamente lugar de búsqueda, en la medida en que obliga al movimiento, a un errar de aquí para allá en pos de una respuesta, pues impele a salir de él. Jabès hablará de un "desamparo, fe, búsqueda incansable de la verdad", pues el desierto será el lugar de persecución de esa certeza última. Quien permanece en el desierto, permanece en el exilio. Continúa Jabès aludiendo a la necesidad del "éxodo, el exilio, para que la palabra despojada de toda palabra -y desde entonces confrontada al silencio- adquiera su verdadera dimensión" ${ }^{52}$. El desierto será el lugar del poeta puesto que resulta necesario atravesarlo para poder acceder a otro ámbito desprovisto ya de razonamientos y de conceptos. En sus lindes se habrá de emplear un habla a mitad de camino entre la humana y la divina, pues no es propiamente tierra de hombres ni de dioses, sino camino de acercamiento y alejamiento hacia ambos. El poeta saldrá al desierto en busca de su yo, se exiliará para reencontrarse. Como espacio abierto, el desierto se revela como ámbito de desorientación, de tanteo, espacio donde uno no distingue dónde se sitúa el centro y dónde la periferia. Por último, sobre la arena, el sol hará su aparición en todo su esplendor, potente, acentuando la opresión ensordecedora sufrida por el poeta.

${ }^{50}$ C. Peinado Elliot (2002), p. 192.

${ }^{51}$ El objeto, como elemento que ejerce su atracción sobre el sujeto lírico, como elemento activo, de acuerdo con Valente

tiene un margen sagrado de libertad en el que la conciencia del poeta no debe pisar, más que a riesgo de destruirlo. El objeto del poema tiene su propio derecho a existir. Dentro de ese margen de libertad, el objeto se manifiesta por sí mismo, se realiza o toma cuerpo en el mundo verbal que el poema le tiende. El proceso creador es un proceso bilateral en el que no interviene sólo el poeta sino en el que el objeto impone también su condición y su ley. J.A. Valente (2011), p. 36.

${ }^{52}$ E. Jabès (2001), pp. 80, 83. 
Puesto que el desierto se corresponde con un inicial periodo del proceso en el que el poeta se abrirá paso hacia un orden de mayor libertad, resultará más observable su presencia en los primeros libros del autor. Así, en el poema "El odio", de Poemas a Lázaro, leemos, "Después se borró todo./ Luchábamos en medio/ de un oscuro desierto/ de arena o de cenizas/ que el odio calcinaba" ${ }^{53}$. Lugar de conflicto, de oposición frente a lo hasta ese momento considerado válido, la desnudez del desierto se asociará a un desmoronamiento de toda realidad, a un descenso a los infiernos caracterizado por la sordidez de lo meramente sensitivo y la correspondiente carencia de fuerzas espirituales. La simbólica expulsión del paraíso, la condena a un eterno errar, se comprenderá como expulsión del centro, salida de la ortodoxia en pos de una deseada heterodoxia.

El desierto será lugar del canto, pero de un canto árido, carente de la riqueza abundante que observaremos en posteriores creaciones del autor, pues, como ya adelantamos, el agua, elemento vivificador por excelencia, no resultará observable en estos primeros estadios recorridos por el poeta. El desierto -según comenta Juan Eduardo Cirlot- es "el «dominio de la abstracción», que se halla fuera del campo vital y existencial, abierto solo a la trascendencia. Además el desierto es el reino del sol, no en su aspecto de creador de energías sobre la tierra, sino como puro fulgor celeste, cegador en su manifestación" ${ }^{54}$. En toda su amplitud, en su extrema desorientación, entre su cegadora arena, se situará Valente con vistas a emprender la búsqueda del objeto.

El poeta será en estas lindes una figura asimilable al profeta. En No amanece el cantor leemos, "No dejéis morir a los viejos profetas pues alzaron su voz contra la usura que ciega nuestros ojos con óxidos oscuros, la voz que viene del desierto, el animal desnudo que sale de las aguas para fundar un reino de inocencia, ${ }^{\text {"55 }}$. Como espacio de aparición, el creador encuentra aquí su ángel, encuentra su voz en estado puro, sin ecos. Por ello, el poeta del desierto será el que tenga más concomitancias con el místico al permanecer entregado a la creación de expresiones directas, secas y ásperas. Será, a su vez, aquí mismo, donde deponga sus imágenes, sus creencias hasta entonces no cuestionadas.

La indagación necesariamente concluirá en el punto de partida, de modo que una vez finalizada esta búsqueda, el yo lírico retornará al desierto para entregarse a morir sobre la arena: "Efímera/ construyo mi morada./ Trazo un gran círculo en la arena/ de este desierto o tiempo donde espero/ y todo se detiene y yo soy sólo/ el punto o centro no visible o tenue/ que un leve viento arrastraría" ${ }^{56}$. Toda manifestación individual termina por desaparecer, quedando el verbo abocado al silencio. "El pensamiento religioso -indica Cassirer- busca siempre nuevas

53 J.A. Valente (2006), p. 124.

${ }^{54}$ J.E. Cirlot (2011), pp. 170-171.

55 J.A. Valente (2006), p. 491.

${ }^{56}$ J.A. Valente (2006), p. 581. 
imágenes para el yo, para el sujeto considerado como lo intangible e incomprensible y también se ve cómo al final sólo puede determinar este yo desechando nuevamente todas esas insuficientes e inadecuadas imágenes plásticas ${ }^{957}$; respuesta similar a la ofrecida por una mística negativa indisociable de la obra de Valente. El cuerpo de la imagen se mantendrá a la espera de una pronta transformación, quedando el espíritu en el aire como gran desconocido de cuanto uno es. Finalizaremos nuestra comprensión del desierto transcribiendo el poema en prosa "Máscaras" como indicativo de cuanto Valente observará en lo relativo a este último aspecto:

¿Qué queda de las personas cuando la persona se disuelve, desaparece, vuela detrás del aire, de las cosas del día, del límite indeciso de la noche, de las demandas imperiosas de su prójimo, del ahora ya casi inexistente amor que un día abrasó el cielo, del horizonte infinito del desierto, de los ríos que son caminos que anduviesen para nunca llevarnos a lugar conocido, del ala de los pájaros, del tumefacto cuerpo devorado de un dios y de sus sacrificadores, del lugar de la llave y el tesoro escondidos, de ti y de mí, qué queda de la sombra?

Quedaría tal vez un puñado inocente de muy breve ceniza y, debajo, el rescoldo, el residuo del fuego, que late aún, del ser que ha sido, del que aún será, del que no será nunca, del que jamás advino.

Disolverse, dijiste, o nacer para siempre más allá de las máscaras ${ }^{58}$.

\section{Elementos vivificantes del universo en creación}

Como mencionamos, la palabra poética será aquélla que nos adentre en terrenos fecundantes, aquélla que dé acceso a toda una serie de imágenes simbólicas nacidas de las aguas como fuerza creadora capaz de derribar todo límite, toda forma anquilosada. El agua, usualmente quedará asociada a la noche como elemento de unión y de confusión, de adentramiento de imágenes vivificadoras en todo tipo de sólidas formaciones, permitiendo así la entrada de la naturaleza creadora en sedimentos en exceso fosilizados. Cercano a esta capacidad generativa, el río se presenta como "símbolo ambivalente por corresponder a la fuerza creadora de la naturaleza y del tiempo"59. Así, en La memoria y los signos leemos, "Como ríos contiguos se combaten los cuerpos,/ desde su propio vértigo rebasan/ el nivel de las aguas,/ rompen cuanto es orilla o valladar o límite,/ sorben hasta agotarlo el cauce próximo,/ hasta llegar al centro sumergido y más hondo,/ que luego, requemado, calcina el sol de mediodía" ${ }^{60}$. Estas aguas fluviales se muestran como representación de un inconsciente vivo, capaz de surgir desde las profundidades poéticas y romper con su fuerza pura, sin mezclarse aún con otros elementos que la

${ }^{57}$ E. Cassirer (2003a), p. 218.

${ }^{58}$ J.A. Valente (2006), p. 532.

${ }^{59}$ J.E. Cirlot (2011), p. 391.

${ }^{60}$ J.A. Valente (2006), p. 184. 
enturbian, todos aquellos moldes construidos por el plano racional. Por ello, señalará Bachelard en El agua y los sueños, que "al margen de toda metáfora, es necesaria la unión de una actividad soñadora y de una actividad ideativa para producir una obra poética" ${ }^{\prime \prime}$.

Las aguas poseen un doble significado, siendo por un lado el lugar de germinación, elemento desde donde canta la voz interior o anima y, por el otro, elemento asociado al devenir, a una fluidez de textura cristalina en la medida en que logra, con su presencia, despojar al mundo material de opacidad. El agua se manifestará como nexo de unión entre el sujeto y el mundo fenoménico. Por ello, como ya pudimos ver, tras un primer periodo de infatigable lucha en el desierto, pronto surgirán los primeros destellos de plenitud vital, de convergencia entre mundo exterior y mirada poética. El agua comienza entonces a entregar su transparencia, abriendo los objetos, haciéndolos más reales, más vivos, una vez que horadando la realidad consigue extraer de ella su fuerza interior, tal y como leemos en otro de los poemas de La memoria y los signos: "Como la tierra seca abre/ su dura entraña al agua" ${ }^{2}$. Asistimos en este verso a un principio germinativo que más adelante posibilitará la consecución de la experiencia poética completa, lograda en el momento en que surgen símbolos axiales donde polaridades en un principio enfrentadas convergen en una sola imagen, sea el árbol, el hombre o la cruz, símbolos que, por lo común, concentrarán toda la potencia creativa manifestada por el universo poético.

Siguiendo con La memoria y los signos leemos un poema, "El moribundo", en el que asistimos a un claro proceso de avivamiento interior, "Rompió la lluvia al fin el cerco oscuro./ Dilatose el recuerdo"63. Las aguas ahondarán en los sustratos poéticos permitiendo la afloración del imaginario, de un plano emotivo hasta el momento constreñido. La lucha contra el ángel iniciada en el desierto dará entonces sus primeros brotes de vida, de transparencia, posibilitando al poeta aliviar su sequedad, su alma hasta ese instante constreñida y dolorosa. A su vez, la lluvia se observará también como elemento aniquilador del pasado, pues, como sustancia transformadora, no sólo vivifica el presente sino que borrará huellas pretéritas, disipando con su presencia imágenes y experiencias ya apenas recordadas: "La lluvia/ parece ya borrar aquel amor" ${ }^{\prime 64}$.

En relación con este aspecto, Díaz Gamboa hará referencia a "un espacio inestable en donde todo se vierte y declina", así como a un "descenso incesante de todas las cosas que se van diluyendo" ${ }^{, 65}$. La asociación del agua con un componente disolutivo será, en estos casos, absoluta, posibilitando por una parte la vida, el

${ }^{61}$ G. Bachelard (2003), p. 22.

62 J.A. Valente (2006), p. 180.

${ }^{63}$ J.A. Valente (2006), p. 181.

${ }^{64}$ J.A. Valente (2006), p. 246.

${ }^{65}$ S.L. Díaz Gamboa (2009), pp. 901-902. 
nacimiento, pero generando a su vez la muerte, el olvido, un deshacerse material consustancial a su naturaleza transformadora.

El poder del agua es el poder de la palabra generadora, capaz de atravesar cualquier sustancia y capaz de disolver la voluntad de toda forma. Como elemento de formación, como reverberación primera del ritmo creador, el agua participa de lleno del poder del verbo. Bachelard asegura que entre palabra y agua hay continuidad, indicando además que "el lenguaje de las aguas es una realidad poética directa" ${ }^{66}$, pues transmite la voz anímica, voz interior inherente al deseo de expresión de la voluntad a través de la conciencia diurna, de la forma. Labor del poeta será, por lo tanto, romper el cerco pétreo, la estéril conciencia, el abismarse en elementos irracionales de modo que se pueda encontrar en ellos todo tipo de imágenes primigenias. El movimiento posibilitado por la acción de las aguas será observado como antojadizo y azaroso en tanto que simplemente libera, dejando abiertas las compuertas pero permaneciendo ajenas al sentido aportado por algún otro elemento de intención ascensional o, en cualquier caso, más firme y manifiesto.

\section{Enigmas}

Como símbolos mediadores entre el agua germinal y el vacío colindante con el absoluto, encontramos el laberinto, el jeroglífico, el jardín y el enigma, figuras todas ellas que hacen su aparición en diferentes momentos de la poesía de José Ángel Valente asociadas siempre a la complicación propia del paso de la materia primera a la forma última. Esta prueba no siempre será superada de modo satisfactorio al darse una gran pérdida de significado a lo largo de dicho recorrido. En referencia a esta cuestión, Juan Eduardo Cirlot, en su diccionario, menciona que Mircea Eliade

señala que la misión esencial del laberinto era defender el centro, es decir, el acceso iniciático a la sacralidad, la inmortalidad y la realidad absoluta, siendo un equivalente de otras pruebas, como la lucha contra el dragón. De otro lado, cabe interpretar el conocimiento del laberinto como un aprendizaje del neófito respecto a la manera de entrar en los territorios de la muerte ${ }^{67}$.

Ambas posibilidades nos son útiles en cuanto que aplicables a la poesía de Valente. A esta segunda aclaración relativa a la entrada en "territorios de la muerte", le corresponderá la figura del sacrificado, siendo el poeta quien, en busca del centro, en pos de alcanzar una realidad absoluta, sostenga una lucha contra el ángel ${ }^{68}$

\footnotetext{
${ }^{66}$ G. Bachelard (2003), p. 30.

${ }^{67}$ J.E. Cirlot (2011), p. 274.

${ }^{68}$ Esta lucha puede corresponderse con la aceptación de un destino nacido de uno mismo, tal y como lo comprende Max Scheler, de modo que el vencimiento o la derrota contra el alter
} 
logrando mantenerse en un eje vertical, ahistórico, y en otro horizontal, existencial, a un mismo tiempo. El creador quedará así sobre el eje de la cruz, centro y periferia del universo observado o, según Jabès, pregunta y respuesta absolutamente fusionadas.

De acuerdo con Robert Langbaum,

el movimiento centrífugo del poema se convierte [...] en un ardid para regresar a su interior, y el contexto dramático deviene mera ocasión para la expresión lírica. Así, el hablante dirige su enunciado hacia el exterior con el fin de interpelar a su persona, y hace un descubrimiento objetivo para descubrirse a sí mismo [...] El hablante transforma las circunstancias en una parte de sí mismo a medida que evoluciona internamente hacia una manifestación más intensa de su propia naturaleza ${ }^{69}$.

Apreciamos en este comentario el movimiento hacia dentro y hacia afuera que rige la naturaleza del poema, tendiendo el uno hacia un estatismo absoluto, hacia una unidad ajena a la diversificación cuantificada, y el otro hacia una serie de manifestaciones que devuelven al cosmos su necesaria pluralidad. El proceso por el que el creador recorre una y otra vez este camino topará con obstrucciones provocadas por una naturaleza racional poco dada a la convergencia de opuestos, dado que su orden queda encaminado a resolver sus tensiones en un plano existencial y no en uno atemporal. En referencia al lenguaje y a su imposibilidad de conducirnos hacia el interior del centro axial, Edmund Jabès comentará que

es el sentimiento de lo invisible lo que nos lleva, paradójicamente, a mirar lo visible como si nunca fuera más que la aproximación. Asimismo, para el escritor, toda palabra escrita oculta esta palabra no completamente inaprensible, pero diferida sin cesar e infinitamente más esencial. Es hacia esa palabra que él se dirige $^{70}$.

El laberinto, de acuerdo con Jabès, conducirá, pero no nos presentará frente a la esfinge. Habrá preguntas, por lo tanto, pero no se alcanzará una respuesta. Valente teorizará en varios ensayos acerca del jardín y el laberinto considerándolos como espacios identificables de salida y entrada en el tiempo, como "precondición o antesala del proceso iniciático en el que hay siempre algo que renace, que es resurrección" ${ }^{71}$. El creador caminará así hacia el núcleo del laberinto, hacia el anima del yo, voz profunda de la creación, tratando de reunir su naturaleza

ego representado por el ángel va a resolverse en la superación, la permanencia o la caída en un estadio espiritual concreto.

${ }^{69}$ R. Langbaum (1996), p. 325.

${ }^{70}$ E. Jabès (2001), p. 122.

${ }^{71}$ J.A. Valente (2008), p. 533. 
consciente con aquella otra inconsciente, posibilitando de esta manera la aparición de la palabra poética.

\section{La ruina, sombra de un orden elevado}

Asociada con este último aspecto concerniente a la mediación entre el nacimiento de la expresión y el objeto designado, observamos la huella o la ruina como indicio del dios; ruina relacionada a su vez tanto con el fragmento como con la sombra generada por la palabra poética. Todos estos elementos serán considerados a modo de recuerdos, de ecos de un pasado ya inexistente o, al menos, lejano, hacia el que el poeta encamina sus pasos. Según indica Eva Valcárcel, "Valente busca la visión en la poesía partiendo de una no visión que augura la visión posible; existe un eco de lo que puede ser, un silencio que guiará hasta los límites del conocimiento al individuo, conduciéndolo hasta la visión" ${ }^{\text {"72 }}$. Este eco convergerá, a su vez, con la palabra poética presentada como fragmento que ha quedado de un lenguaje milenario en el que la voz estuvo ligada absolutamente a la creación. Habrá, por esto mismo, que desvelar el significado borrado de las palabras para alcanzar la verdadera forma restituida: "¿Quién vendrá de lo alto/ con fragmentos de viento/ a darte nombres?" ${ }^{73}$, se preguntará el autor. Los versos, con ecos propios de Rilke, vienen precedidos de una estrofa más explícita aún: "Manada ciega/ de animales oscuros/ volcados sobre el barro". Obviamente, al aludir a estos "animales oscuros" el poeta está haciendo referencia a una expresión sucia aún, recién salida de su estado larvario. Será necesaria la unión divina, la filtración del espíritu en la materia, para que el verbo cobre vida y tienda una parábola mística hacia su extinción.

Según señala Valente en uno de los textos que componen el Elogio del calígrafo, "En el mundo tribal, chamánico, cada individuo sabía que el poder real reside no en la forma externa de una cosa, sino en su forma secreta, interior, en su escondido, y que llegar a alcanzar ese escondido era la finalidad del ritual, mientras que narrar ese encuentro era la finalidad del mito" ${ }^{, 74}$. La divinidad que dejó sus huellas, sus ruinas, no habrá de buscarse en un espacio exterior, sino precisamente en su interior. En este sentido, estas figuras poseerán una función afín a la ofrecida por la aparición del jardín, del laberinto, del enigma y, por proyección, del centro o de la piedra, una vez que en su seno se esconderá el dios como unidad superior. En estas imágenes, como sabemos, convergen a un tiempo el enmascaramiento de la forma creativa junto con el desvelamiento del signo que guía hacia ese desconocido dios.

${ }^{72}$ E. Valcárcel (1989), p. 69.

73 J.A. Valente (2006), p. 464.

${ }^{74}$ J.A. Valente (2008), p. 517 
Por supuesto, estas ideas van a guardar relación con la noción de residuo mencionada una y otra vez por el poeta en sus textos críticos, pues cuanto observaremos no es sino aquello que permanece de la voz a través del tiempo:

Lo que se lee, una vez más, es la huella o rastro de la vida. Y de esa materia parece estar hecha también la poesía: marca de lo ausente, eso o residuo de un resplandor sin memoria. Las palabras remiten al reshima de la doctrina de Isaac Luria: ese resto divino, casi imperceptible, que quedó en el espacio vacío tras el acto de Tsimtsum, y del que nacen los prodigios del mundo ${ }^{75}$.

Con ello podemos simplificar que, al desaparecer la forma creadora, espiritual, cuanto nos quede de la palabra viva será la materia, el residuo, eco o huella, lejana ya del ritmo inmanente a la creación; lejana, por otra parte, a una realidad de la cual, en un principio, la voz no se había aún diferenciado. El sentido de la creación podrá, en consecuencia, rastrearse a través de dichas huellas, siendo, según Schneider, en ellas más importante su sonoridad que su comprensión lógica:

la música es la más alta espiritualización de la Naturaleza, porque expresa esta Naturaleza con un mínimo de materia. Realza y ennoblece todo cuanto expresa porque en ella todo es forma y substancia. Pero todas las tradiciones místicas convienen en que para comprender este lenguaje hace falta entregarse al ritmo creador y no con el fin de disecarlo, sino tan sólo para vivirlo ${ }^{76}$.

A través de estos residuos manifestados en la poesía, convergentes en ocasiones con su completa sustancia, cuanto se percibe será un ritmo aunado de raíz al dios, ritmo que nos pone en contacto con los orígenes, con la luz interior.

La lengua actual, se lamentará Valente, tan intelectualizada, tan alejada de sus fundamentos, mostrará tan sólo los muros derruidos de una inmensa catedral, creación humana y a un tiempo divina que antaño se elevó: "QUEDAR/ en lo que queda/ después del fuego,/ residuo, sola/ raíz de lo cantable" ${ }^{\text {"77 }}$. Este último poema aludirá tanto a la propia esencia de la expresión como al proceso sufrido por el creador. La creación, en sí misma, es, por consiguiente, símbolo, imagen incompleta de la totalidad, imagen que, sin embargo, se manifiesta capaz de guiarnos hasta el dios.

Hasta aquí hemos analizado algunos de los símbolos fundamentales de la poesía de José Ángel Valente. Alrededor de ellos girará una multitud de imágenes que dotarán de abundancia y colores al universo creativo. En definitiva, cuanto vamos

\footnotetext{
${ }^{75}$ E. Marín Ortega (2009), p. 358.

${ }^{76}$ M. Schneider (2010), p. 163.

${ }^{77}$ J.A. Valente (2006), p. 465.
} 
presenciando obedece a la proliferación constante de múltiples formas proyectadas desde los espacios seminales en pos de una esencia inalcanzable, a través de una serie de agrupaciones simbólicas conformadas a modo de brazos irradiantes de luz, vida, fuerza y atracción. El símbolo, por todo ello y según hemos venido observando, básicamente será el elemento que aúne una condición existencial con aquella otra esencial; lo presentado de modo cuantitativo, con cuanto se manifiesta unitariamente como fuente primera de verdad.

\section{Obras citadas}

BACHELARD, Gaston: El agua y los sueños, México, Fondo de Cultura Económica, 2003.

BACHELARD, Gaston: La tierra y las ensoñaciones del reposo, México, Fondo de Cultura Económica, 2006.

CaÑas, Dionisio: Poesía y percepción. (Francisco Brines, Claudio Rodríguez y José Ángel Valente), Madrid, Hiperión, 1984.

CASSIRER, Ernst: An essay on man, New Haven-London, Yale University Press, 1972.

CASSIRER, Ernst: Filosofía de las formas simbólicas II, México, Fondo de Cultura Económica, 2003a.

CASSIRER, Ernst: Filosofía de las formas simbólicas III, México, Fondo de Cultura Económica, 2003b.

CIRLOT, Juan Eduardo: Diccionario de símbolos, Madrid, Siruela, 2011.

CIRLOT, Victoria: La visión abierta, Madrid, Siruela, 2010.

CORBIN, Henry: La imaginación creadora en el sufismo de Ibn'Arabî, Barcelona, Destino, 1993.

CORBIN, Henry: El hombre de luz en el sufismo iranio, Madrid, Siruela, 2000.

DíAZ GAMBOA, Sandra Lucía: «La experiencia de los límites en la obra de José Ángel Valente y sus implicaciones lógico-matemáticas», tesis doctoral defendida en la UNED, Madrid, 2009.

DURAND, Gilbert: La imaginación simbólica, Madrid, Amorrortu, 2007.

EIGELDINGER, Marc: Poésie et metamosphoses, Neuchatel, Éditions de La Baconnière, 1973.

GuÉNON, René: El simbolismo de la cruz, Palma de Mallorca, Olañeta, 2003.

GUÉNON, René: La gran tríada, Barcelona, Paidós, 2004.

HEIDEGGER, Martin: El arte y el espacio, Barcelona, Herder, 2009.

JABĖS, Edmond: Del desierto al libro, Córdoba (Argentina), Alción, 2001.

JUNG, Carl Gustav: Psicología y alquimia, Madrid, Trotta, 2005.

JunG, Carl Gustav: La vida simbólica I, Madrid, Trotta, 2009.

LANGBAUM, Robert: La poesía de la experiencia, Granada, Comares, 1996.

MAN, Paul de: Visión y ceguera, Puerto Rico, Universidad de Puerto Rico, 1991. 
MARTíN ORTEGA, Elisa: «Cábala y poesía. Ejemplos hispánicos», tesis doctoral defendida en la Universidad Pompeu Fabra, Barcelona, 2009.

NOËL, Bernard: «Valente, poesía y estética», en José Ángel Valente: El Fulgor y las tinieblas, Claudio Rodríguez Fer (Ed.), Lugo, Axac, 2008, pp. 29-36.

PAYERAS GRAU, María: «El don de lo imposible», Espacio/ Espaço Escrito, 6-7 (1991), pp. 34-38.

PEINADO ELLIOT, Carlos: «La imagen banal y la palabra única: en torno a un poema de José Ángel Valente», Comunicación: Revista Internacional de Comunicación Audiovisual, Publicidad y Estudios Culturales, 1 (2002), pp. 189-201.

Río SURRIBAS, Juan Manuel del: «El ángel y el náufrago. Estudio de la convergencia poética de José Ángel Valente y Emilio Adolfo Westphalen», tesis doctoral defendida en la Universidad de A Coruña, A Coruña, 2009.

ROMARÍs PAIS, Andrés: «José Ángel Valente: Sobre el cantor y su memoria», Moenia, 6 (2000), pp. 143-175.

SCHNEIDER, Marius: El origen musical de los animales-símbolos en la mitología y la escultura antiguas, Madrid, Siruela, 2010.

SHERNO, Sylvia R.: «José Ángel Valente: From the Dark Centre to the Limits», Revista canadiense de estudios hispánicos, XIV, 1 (1989), pp. 161-173.

VALCÁRCEL LÓPEZ, Eva: El fulgor o la palabra encarnada. Imágenes y símbolos en la poesía última de José Ángel Valente, Barcelona, PPU, 1989.

VALente, José Ángel: Obras completas 1. Poesía y prosa, Barcelona, Galaxia Gutemberg/ Círculo de Lectores, 2006.

VAlENTE, José Ángel: Obras completas 2. Ensayos, Barcelona, Galaxia Gutemberg/ Círculo de Lectores, 2008.

VALENTE, José Ángel: Diario anónimo (1959-2000), Barcelona, Galaxia Gutemberg/ Círculo de Lectores, 2011. 